\title{
Correction to: Design, synthesis, conformational and molecular docking study of some novel acyl hydrazone based molecular hybrids as antimalarial and antimicrobial agents
}

Parvin Kumar ${ }^{1 *} \oplus$, Kulbir Kadyan ${ }^{1}$, Meenakshi Duhan ${ }^{1}$, Jayant Sindhu², Vineeta Singh ${ }^{3}$ and Baljeet Singh Saharan ${ }^{4}$

\section{Correction to: Chemistry Central Journal (2017) 11:115 https://doi.org/10.1186/s13065-017-0344-7}

After publication of the original article [1], the following error was reported in the Results section of the Abstract: "antifungal activity against one yeast i.e. Aspergillus niger" should read: "antifungal activity against one fungus i.e. Aspergillus niger". The authors would like to confirm all antifungal activity has been screened against fungi not yeast.

This error has been corrected in the original article [1].

\section{Author details}

1 Department of Chemistry, Kurukshetra University, Kurukshetra 136119, India. ${ }^{2}$ S D (PG) College, Panipat 132103, India. ${ }^{3}$ National Institute of Malaria Research, Dwarka, New Delhi 110077 , India. ${ }^{4}$ Department of Microbiology, Kurukshetra University, Kurukshetra 136119, India.

\section{Publisher's Note \\ Springer Nature remains neutral with regard to jurisdictional claims in pub- lished maps and institutional affiliations.}

Published online: 06 February 2018

\section{Reference}

1. Kumar P, Kadyan K, Duhan M, Sindhu J, Singh V, Saharan BS (2017) Design, synthesis, conformational and molecular docking study of some novel acyl hydrazone based molecular hybrids as antimalarial and antimicrobial agents. Chemistry Central Journal 11:115. https://doi.org/10.1186/ s13065-017-0344-7

Full list of author information is available at the end of the article provided you give appropriate credit to the original author(s) and the source, provide a link to the Creative Commons license, and indicate if changes were made. The Creative Commons Public Domain Dedication waiver (http://creativecommons.org/ publicdomain/zero/1.0/) applies to the data made available in this article, unless otherwise stated. 